ISSN 0258-7122 (Print), 2408-8293 (Online)

Bangladesh J. Agril. Res. 44(2): 291-301, June 2019

\title{
GENETIC VARIABILITY, CORRELATION AND PATH ANALYSIS FOR YIELD AND ITS COMPONENT TRAITS IN RESTORER LINES OF RICE
}

\author{
M. Z. ISLAM ${ }^{1}$, M. A. K. MIAN ${ }^{2}$, N. A. IVY ${ }^{3}$ \\ N. AKTER ${ }^{4}$ AND M. M. RAHMAN ${ }^{5}$
}

\begin{abstract}
Twenty nine restorer lines of rice were evaluated for fourteen agromorphological traits during Boro (irrigated rice) season of 2012-2013 at Bangabandhu Sheikh Mujibur Rahman Agricultural University (BSMRAU), Gazipur, and Bangladesh. Analysis of variance revealed significant differences among the restorer lines for all the traits studied.The phenotypic coefficient of variation (PCV) was higher than genotypic coefficient of variation (GCV) for all the traits indicating the presence of little environmental influence in the phenotypic expression. Heritability estimate was found high for all the yield contributing traits. High heritability along with high genetic advance as per cent of mean was recorded for secondary branches per panicle followed by number of effective tillers, flag leaf area and panicle weight. Contrary, days to flowering and days to maturity showed high heritability coupled with low genetic advance as per cent of mean. Pearson correlation revealed grain yield had positive association with number of effective tillers per hill, panicle length, spikelet fertility, flag leaf area, plant height and thousand grain weights. Mentioned characters also found positive association with yield in both genotypic and phenotypic level. Spikelet fertility, number of secondary branches per panicle, thousand grain weights and number of effective tiller possessed higher positive direct effect on grain yield. It indicated the importance of these traits as selection criteria of yield improvement in hybrid rice programme.
\end{abstract}

Keywords: Variability, Heritability, Correlation, Path Co-efficient, Restorer line and Rice

\section{Introduction}

Rice occupies more than $75.01 \%$ of total cropped area of Bangladesh (BBS, 2015). It provides $75 \%$ of the calories and $55 \%$ of the proteins in the average daily diet of the people (Bhuiyan et al., 2002). To feed the ever increasing population, there is no option other than breaking the yield ceiling of rice. Thus, breeding programs are effective and essential for improving the present varieties and increasing of yield.

\footnotetext{
${ }^{1 \& 4}$ Genetic Resources and Seed Division, Bangladesh Rice Research Institute (BRRI), Gazipur -1701, ${ }^{2 \& 3}$ Bangabandhu Sheikh Mujibur Rahman Agricultural University (BSMRAU), Gazipur -1706, ${ }^{5}$ Regional Station-Satkhira, Bangladesh Rice Research Institute (BRRI), Bangladesh.
} 
Hybrids may offer to make a breakthrough in the yield ceiling of semi-dwarf rice that began in 1964. The discovery of CMS system in rice (Athwal and Virmani, 1972) suggested that breeding could develop a commercially viable $F_{1}$ hybrid. Currently, hybrid rice technology is considered as a viable option to increase rice yield globally. China is the first country to exploit heterosis commercially in rice. During late 90 's, about $55 \%$ of the rice area in China was under hybrid rice, producing $66 \%$ of the total rice production (Virmani et al., 1998). Presently, hybrid rice covers $70 \%$ of the total rice area which is about 20 million hectares. The most promising hybrids yielded $20-30 \%$ and $15-20 \%$ (Yuan, 1998) higher than the best conventional and modern rice varieties, respectively. Initially, after the introduction of hybrid rice in Bangladesh in 1998, over the last one and half decades, about 174 rice hybrids were released for commercial cultivation in different rice growing regions of the country. The area planted to hybrid rice in the country during Boro 2016-17 was around 0.7 Mha has contributed 3-4 MT of additional rice to the total rice production in the country (AIS, 2018).

At present, the hybrid seed production in rice is primarily based on the three-line hybrid system, which involves a CMS line or "A" line, a corresponding isonuclear maintainer (B) line, and a genetically diverse restorer (R) line. A line is maintained by crossing it with B line. In hybrid seed production, A line is crossed with $\mathrm{R}$ line and $\mathrm{R}$ line possesses dominant fertility restorer gene(s), the resultant $\mathrm{F}_{1}$ used for commercial hybrid is fertile. So, $\mathrm{R}$ lines play an important role in three line hybrid rice production.

Genetic variation is the basis of plant breeding and provides a great array of genotypes that can be selected to develop new varieties or breeding materials (Pandey et al., 2009). Variability in terms of genetic divergence for agronomic traits is the key component of breeding programmes for broadening the gene pool of rice and requires reliable estimates of heritability to plan an efficient breeding strategy (Akinwale et al., 2011). Information on association of characters, direct and indirect effects contributed by each character towards yield will be an added advantage in aiding the selection process (Singh et al., 2018).

The knowledge regarding relative contribution of individual traits to yield may be accomplished by correlation studies. However, simple correlation does not provide the adequate information about the contribution of each factor towards yield. Therefore, the technique of path coefficient analysis is utilized to have an idea of direct and indirect contribution of a trait towards the yield, the end product (Lakshmi et al., 2017). Therefore, this study was conducted to identify the most important characters for breeding programme by exploiting the genetic variation, heritability, and path analysis of yield and related attributes of 29 restorer lines of rice. 


\section{Materials and Methods}

A total of twenty nine (29) restorer lines of rice (Table 1) were collected from Department of Plant breeding and Genetics, Bangabandhu Sheikh Mujibur Rahman Agricultural University (BSMRAU). The R lines were grown at BSMRAU farm during Boro season of 2012-2013 using a randomized complete block design with three replications. Thirty days old seedlings of each $\mathrm{R}$ lines of rice were transplanted on the 5 January, 2013 using single seedling per hill in $2.4 \mathrm{~m}^{2}$ plot with $25 \mathrm{~cm}$ and 20 $\mathrm{cm}$ space between rows and plants, respectively. Fertilizers were applied @ 290:130:120:100:15 kg Urea-TSP-MP- Gypsum- $\mathrm{ZnSO}_{4}$ per hectare. Total Urea was applied in three splits at 15 days after transplanting (DAT), 35 DAT, and just before flowering. Intercultural operations and pest control measures were done as and when necessary during the whole growing period. Observation was made from ten selected plants and data were taken on flag leaf area $\left(\mathrm{cm}^{2}\right)$, plant height $(\mathrm{cm})$, effective tiller number, days to flowering, days to maturity, panicle length $(\mathrm{cm})$, five panicle weight (g), primary braches per panicle, secondary branches per panicle, spikelet fertility $(\%)$, grain length $(\mathrm{mm})$, grain breadth $(\mathrm{mm}), 1000$ - grain weight $(\mathrm{g})$ and yield per 10- hills (g).

Genotypic and phenotypic co-efficient of variation were calculated following the methodology delineated by Burton (1952), while the estimates of heritability and genetic advance were computed as per the procedures elaborated by Burton and Devane (1953), and Johnson et al. (1955), respectively. Normal Pearson's correlation and path coefficient analysis was undertaken using $\mathrm{R}$ software (version 3.2.1). Furthermore, Genotypic and phenotypic correlation coefficients were calculated with META-R software.

Table 1. List of 29 restorer lines of rice

\begin{tabular}{|c|c|c|}
\hline Name of restorer lines & $\begin{array}{c}\text { Total } \\
\text { number }\end{array}$ & Source \\
\hline $\begin{array}{l}\text { BHD 1R, BHD 2R, LP 106R, LP 108R, BU 1R, IR } \\
\text { 509R, BU 521R, Metal R, Moyna R, SL 8R, HB 09R, } \\
\text { BHD 3R, Heera 2R, Heera 5R, Heera 10R, ACI 1R, LP } \\
\text { 70R, Gold R, Doyel R, BU 507R, BU 329R, Shakti R, } \\
\text { HB 8R, BU 7R, BU 3R, BU 11R, China 2R, China 1R, } \\
\text { BU 2R }\end{array}$ & 29 & *BSMRAU \\
\hline
\end{tabular}

*BSMRAU= Bangabandhu Sheikh Mujibur Rahman Agricultural University

\section{Results and Discussion}

The analysis of variance revealed highly significant variations among the $\mathrm{R}$ lines for all the characters studied (Table 2). The phenotypic coefficient of variation (PCV) was higher than genotypic coefficient of variation (GCV) for all the characters studied indicating the presence of environmental influence to some degrees in the phenotypic expression of characters. GCV was the highest (23.61) for number of secondary branches followed by yield (22.85) and flag leaf area 
(21.87) indicated higher degree of genetic variability among the tested lines for these traits. Heritability estimates in broad sense $\left(\mathrm{h}^{2} \mathrm{~b}\right)$ were relatively higher for almost all the traits studied except for spikelet fertility. Iftekharuddaula et al. (2001) and Hasan et al. (2011) also reported similar results in hybrid rice. High heritability estimates have been found to be helpful in making selection of superior genotypes on the basis of phenotypic performance. Heritability estimates along with genetic gain would be more useful for selecting the best individual. The estimate of heritability were high for number of effective tiller (99.98\%), days to maturity $(99.98 \%)$, panicle weight $(99.97 \%)$, thousand grain weight (99.97\%) and number of secondary branches (99.95\%) due to high genetic causes. High heritability along with high genetic advance as per cent of mean was recorded for number of effective tillers, panicle weight, number of secondary branches, thousand grain weight, leaf area index and yield. Islam et al. (2016) reported similar findings for secondary branches per panicle and 1000 grain weight. These findings of our study indicated the less influence of environmental effect in the inheritance of these traits. High heritability coupled with low genetic advance as per cent mean were observed in days to maturity, days to flowering and and plant height. Similar result was observed by Akinwale et al. (2011) for days to heading, days to maturity, plant height and panicle length.

Table 2. Estimation of genetic parameters of yield and its component traits in restorer lines of rice

\begin{tabular}{l|l|l|l|l|l|l|l|l|l}
\hline & Mean & Range & $\mathrm{V}_{\mathrm{p}}$ & $\mathrm{V}_{\mathrm{g}}$ & $\mathrm{PCV}$ & $\mathrm{GCV}$ & $\mathrm{h}_{\mathrm{b}}^{2}$ & $\begin{array}{l}\text { GA } \\
(5 \%)\end{array}$ & GAPM \\
\hline FLA & 37.57 & $25.60-57.42$ & 67.16 & 66.55 & 21.97 & 21.87 & 99.10 & 12.83 & 34.41 \\
PH & 106.97 & $94.83-119.56$ & 45.70 & 44.79 & 6.32 & 6.26 & 98.01 & 10.47 & 9.79 \\
ET & 11.00 & $7.00-16.00$ & 5.48 & 5.49 & 20.84 & 20.82 & 99.98 & 3.70 & 32.89 \\
DF & 129.00 & $121.00-141.00$ & 26.12 & 26.09 & 3.95 & 3.94 & 99.89 & 8.07 & 6.23 \\
DM & 156.00 & $149.00-167.00$ & 25.81 & 25.83 & 3.27 & 3.26 & 99.98 & 8.03 & 5.16 \\
PL & 25.81 & $22.63-29.33$ & 3.00 & 2.98 & 6.71 & 6.69 & 99.33 & 2.72 & 10.53 \\
Pwt & 17.84 & $11.42-28.10$ & 13.46 & 13.45 & 20.71 & 20.70 & 99.97 & 5.79 & 32.70 \\
NPB & 10.59 & $9.06-14.73$ & 1.76 & 1.73 & 12.63 & 12.52 & 98.29 & 2.06 & 19.61 \\
NSB & 26.11 & $18.03-41.30$ & 37.38 & 37.36 & 23.64 & 23.61 & 99.95 & 9.66 & 37.33 \\
SF & 78.76 & $65.67-88.67$ & 33.82 & 28.99 & 8.96 & 8.30 & 85.72 & 7.88 & 12.14 \\
GL & 9.82 & $8.82-11.07$ & 0.20 & 0.19 & 4.55 & 4.47 & 96.49 & 0.68 & 6.94 \\
GW & 2.71 & $2.08-3.17$ & 0.07 & 0.06 & 9.66 & 9.38 & 94.17 & 0.39 & 14.38 \\
TGW & 28.91 & $21.67-33.67$ & 12.98 & 12.98 & 17.68 & 17.67 & 99.97 & 5.69 & 27.93 \\
Y/H & 19.29 & $10.73-25.47$ & 20.44 & 19.60 & 23.34 & 22.85 & 95.86 & 6.85 & 35.35 \\
\hline
\end{tabular}

$\mathrm{V}_{\mathrm{p}}=$ Phenotypic variance, $\mathrm{V}_{\mathrm{g}}=$ Genotypic variance, $\mathrm{PCV}=$ Phenotypic Coefficient of variation, $\mathrm{GCV}=$ Genotypic coefficient of variation, $\mathrm{h}_{\mathrm{b}}{ }_{\mathrm{b}}=$ Heritability (Broad sense), GA $=$ Genetic advance, GAPM $=$ Genetic advance in percent of mean 
FLA = Flag leaf area $\left(\mathrm{cm}^{2}\right), \mathrm{PH}=$ Plant height $(\mathrm{cm}), \mathrm{ET}=$ Effective tiller number , $\mathrm{DF}=$ Days to flowering, $\mathrm{DM}=$ Days to maturity, $\mathrm{PL}=$ panicle length $(\mathrm{cm}), \mathrm{Pwt}=$ panicle weight $(\mathrm{g}), \mathrm{NPB}=$ Primary braches per panicle, $\mathrm{NSB}=$ Secondary branches per panicle, $\mathrm{SF}=$ Spikelet fertility $(\%), \mathrm{GL}=\mathrm{Grain}$ length $(\mathrm{mm}), \mathrm{GB}=$ grain breadth $(\mathrm{mm})$, TGW=1000grain weight $(\mathrm{g}), \mathrm{Y} / \mathrm{H}=$ yield per hill $(\mathrm{g})$

The genotypic and phenotypic associations of grain yield with other characters are presented in Table 3. Simple correlation reveals the strong significant association of yield with spikelet fertility and number of effective tiller. The genotypic correlation coefficients in most cases were higher than their phenotypic correlation coefficients indicating the genetic reason of association. In some cases phenotypic correlation coefficient were higher than genotypic correlation indicating suppressing effect of the environment which modified the expression of the characters at phenotypic level.

Grain yield was positively correlated with number of effective tillers per hill, panicle length, spikelet fertility and 1000- grain weight. These results were in partial conformity with those of Akinwale et al. (2011) for number of tillers per plant, panicle weight and the number of grains per panicle and Pandey et al. (2012) for biological yield per plant, flag leaf area and spikelet fertility and Singh et al. (2012) for panicle length, total number of tillers per plant and test weight. Eradasappa et al. (2007) reported significant positive correlation for spikelet fertility percentage with yield in rice. Akter et al. (2018) found positive correlation of effective tiller with yield. Days to $50 \%$ flowering and days to maturity was negatively correlated with yield that means early maturing variety produced lower yield.

Plant height showed significant and positive correlation with flag leaf area, panicle length and panicle weight both at genotypic and phenotypic level (Table 3). Mirza et al. (1992) reported positive correlation of number of panicles $/ \mathrm{m}^{2}$ and grain yield with number of tillers/plant. Days to flowering showed significant positive correlation with days to maturity. Panicle weight possessed positively significant association with flag leaf area and plant height. Moreover, flag leaf area had positive and significant correlation with the number of primary and secondary branches. Numbers of effective tiller showed highly significant positive correlation with spikelet fertility and yield both at genotypic and phenotypic level. Spikelet fertility showed strong positive association with yield both at genotypic and phenotypic level. Kumar et al. (1998) observed high positive correlation of grain yield with spikelet fertility.

Path coefficient analysis (Table 4) revealed that spikelet fertility possessed the highest positive effect on grain yield followed by number of secondary branches per panicle, days to flowering and 1000- grain weight. This indicated that more filled grains in panicle were the highly reliable component of grain yield. These three characters should be given prior attention in rice improvement program because of their major influence on yield which is supported by Hasan et al. 


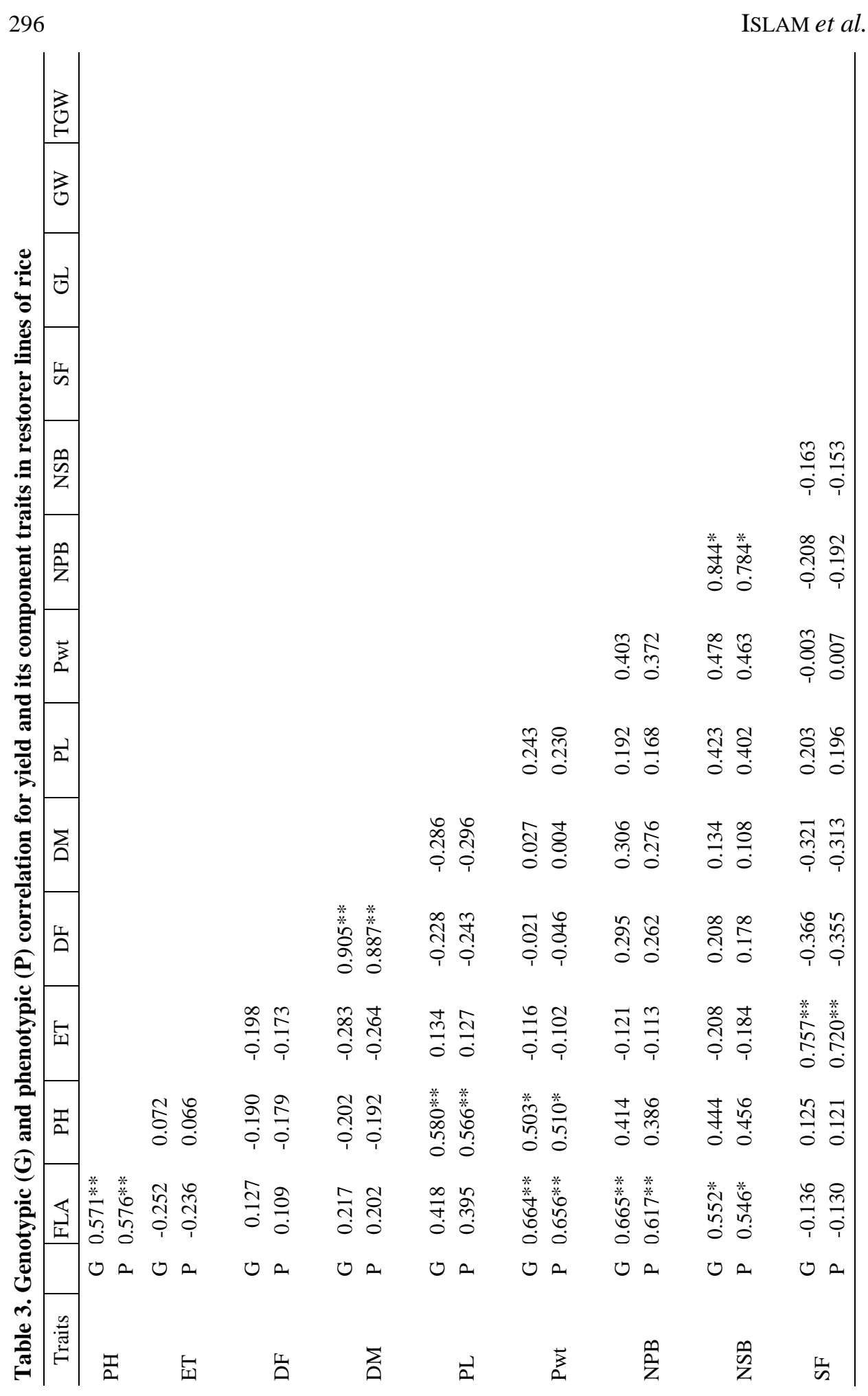




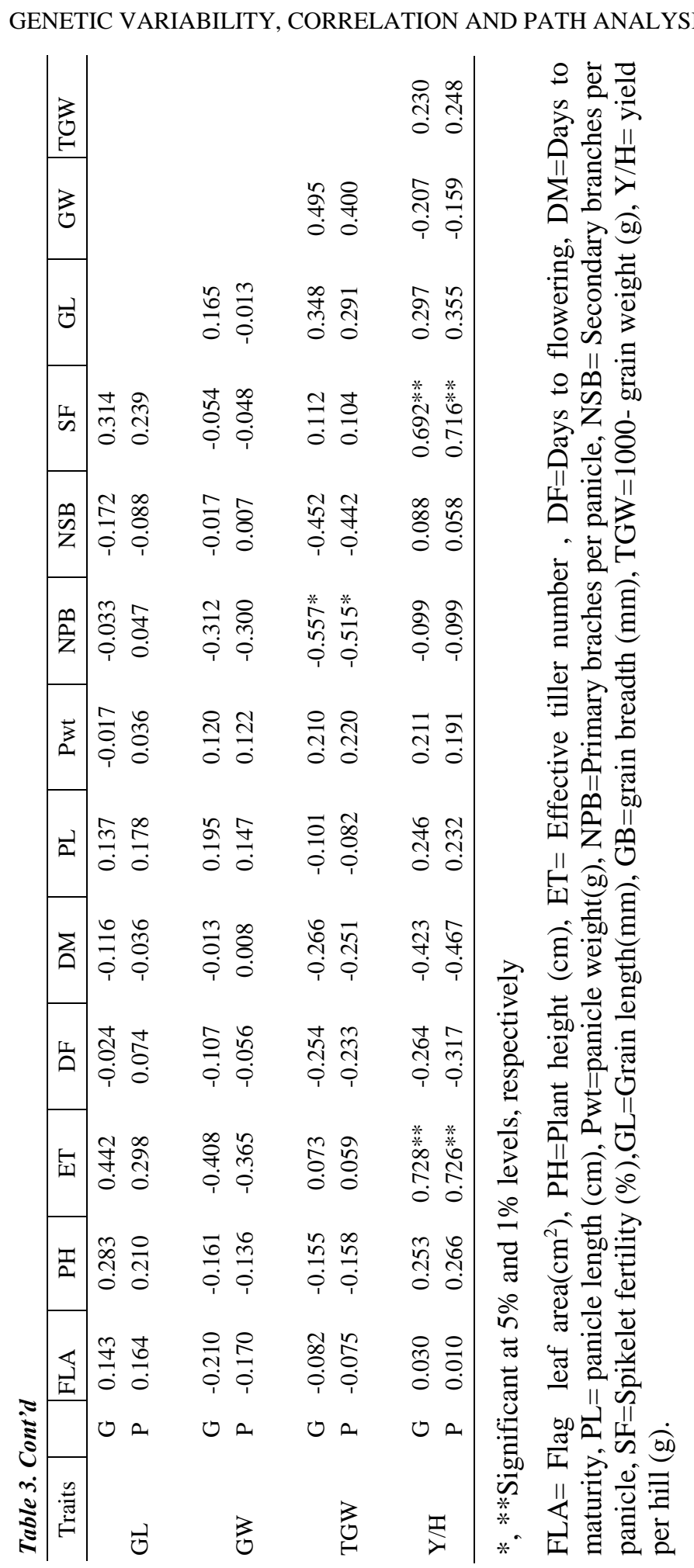




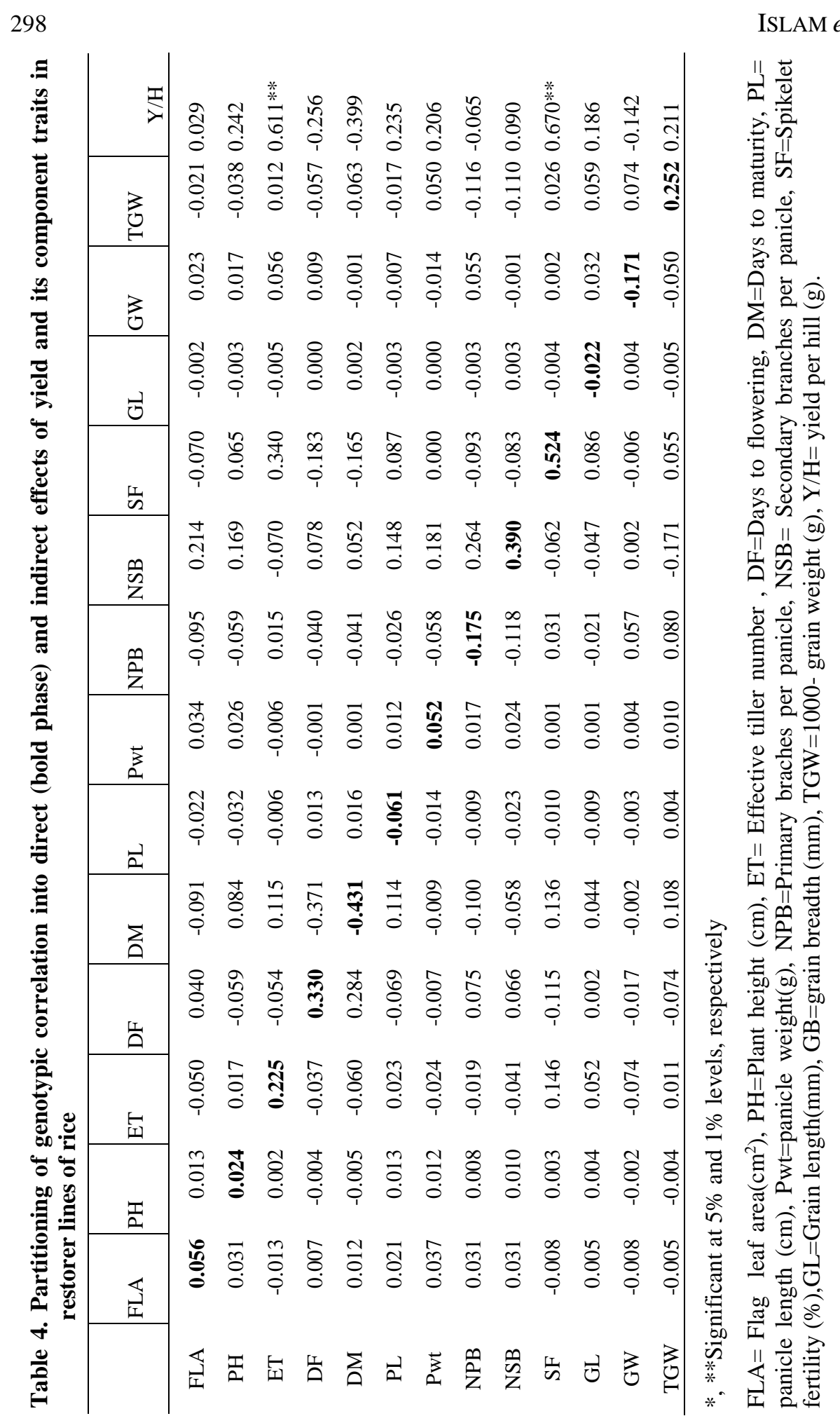


(2010) and Garg et al. (2010). Days to flowering and days to maturity had negative effect with yield. Kumar et al. (2018) reported similar findings in rice. Negative direct effect was observed for number of days to maturity, panicle length, number of primary branches, grain length and grain width. The residual effect of the present study was 0.299 indicated $70.1 \%$ of the variability was accounted for 14 yield contributing traits. This result gave an impression that the rest amount of variability might be controlled by other yield contributing traits that was not considered in the present study.

Significant genetic variability among the yield contributing traits of 29 restorer lines of rice, depicted their superiority in contribution of variation in the study. Furthermore, considering the results of character association and path analysis it is indicated that effective tiller number, percentage of spikelet fertility and 1000grain weight may be considered for yield improvement.

\section{Acknowledgments}

The authors are highly grateful to Prof. Dr. M. A. Khaleque Mian, Department of Plant Breeding and Genetics, Bangabandhu Sheikh Mujibur Rahman Agricultural University (BSMRAU) for providing all necessary supports.

\section{References}

AIS (Agricultural Information Service), 2018. Krishi Diary 2016, Dept. of Agricultural Extension,, Khamarbari, Farmgate, Dhaka-1215, Bangladesh.

Akinwale, A. G., G. Gregorio, F. Nwilene, B. O. Akinyele, S. A. Ogunbayo and A. C. Odiyi. 2011. Heritability and correlation coefficient analysis for yield and its components in rice (Oryza sativa L.). African J. Plant Sci. 5: 207-212.

Akter, N., M. Khalequzzaman, M. Z. Islam, M. A. A. Mamun and M. A. Z. Chowdhury. 2018. Genetic variability and character association of quantitative traits in jhum rice genotypes. SAARC J. Agri. 16(1): 193-203.

Athwal, D.S. and S.S. Virmani. 1972. Cytoplasmic male sterile and hybrid breeding in rice. In: Rice Breeding. IRRI, Manila, Philippines, 615-620pp.

BBS (Bangladesh Bureau of Statistics), 2015. Year Book of Agricultural Statistics of Bangladesh, Planning Division, Ministry of Planning, Govt. of the People's Republic of Bangladesh, Dhaka. pp 23-27.

Bhuiyan, N. I., D. N. R. Paul and M. A. Jabbar. 2002. Feeding the extra millions by 2025 challenges for rice research and extension in Bangladesh. A key note paper presented on national workshop on rice research and extension 2002. Held on 29- 31 January, 2002, BRRI. P.9.

Burton, G.W. 1952. "Quantitative inheritance in grasses," in Proceedings of the International Grassland Congress, vol. 1, pp. 277-283, State College, Pa, USA.

Burton, G. W. and E. H. Devane. 1953. Estimating heritability in tall fescue (Festuca arundinaceae) from replicated clonal material. Agron. J. 45: 478-481. 
Eradasappa E, N. Nadarajan, K. N. Ganapathy, J. Shanthala and R. G. Satish. 2007. Correlation and path analysis for yield and its attributing traits in rice (Oryza sativa L.). Crop Research. 34 (1\&2): 156-159.

Garg, P., D. P. Pandey and D. Singh. 2010. Correlation and path analysis for yield and its components in rice (Oryza sativa L.). Crop Improvement. 37(1): 46-51.

Hasan, M. J., M. U. Kulsum, N. Hoque, M. A. Miah and F. A. M. S. Azam. 2010. Genetic variability, correlation and path coefficient analysis in some restorer lines of hybrid rice (Oryza sativa L.). Eco-friendly Agril. J. 3(5): 222-226.

Hasan, M. J., M. U. Kulsum, A. Akter, A. S. M. Masuduzzaman and M. S. Ramesha. 2011. Genetic variability and character association for agronomic traits in hybrid rice (Oryza Sativa L). Bangladesh J. Pl. Breed. Genet. 24(1): 45-51.

Iftekharuddaula, K. M., M. S. Hasan, M. J. Islam, M. A. Badshah, M. R. Islam and K. Akter. 2001. Genetic evaluation and selection criteria of hybrid rice in irrigated ecosystem of Bangladesh. Pakistan Journal of Biological Sciences, 4(7): 790-792.

Islam, M. Z., M. Khalequzzaman, M. K. Bashar, N. A. Ivy, M. M. Haque and M. A. K. Mian. 2016. Variability assessment of aromatic and fine rice germplasm in Bangladesh based on quantitative traits. The Sci.World J.1-14.

Janaiah, A. and M. Hossain. 2000. Hybrid rice for food security in the tropics: An evaluation of farm-level experience in India. Paper presented at the $3^{\text {rd }}$ Intl. Crop Sci. Congress held in Hamburg, Germany, 17-22 August, 2000.

Jonson, H. W., H. F. Robinson and R. E. Comstock. 1955. Estimates of genetic and environmental variability in soybean. Agron. J. 47(7): 314-318.

Kumar, G. S., M. Mahadevappa and M. Rudraradhya. 1998. Studies on genetic variability, correlation and path analysis in rice during winter across the locations. Karnataka Journal of Agricultural Science. 11(1): 73-77.

Kumar, S., M. P. Chauhan, A. Tomar, R. K. Kasana and N. Kumar. 2018. Correlation and path coefficient analysis in rice (Oryza sativa L.). The Pharma Innovation Journal. 7(6): 20-26.

Lakshmi, L., M. V. B. Rao, C. S. Raju and S. N. Reddy. 2017. Variability, Correlation and Path Analysis in Advanced Generation of Aromatic Rice. Int. J. Curr. Microbiol. App. Sci. 6(7): 1798-1806.

Mirza, M. J., F. A. Faiz and A. Mazid. 1992. Correlation studies and path analysis of plant height, yield and yield components in rice (Oryza sativa L). Sarhad J. Agric., 8(6): 647-653.

Pandey, P., P. J. Anurag, D. K. Tiwari, S. K. Yadav, and B. Kumar. 2009. "Genetic variability, diversity and association of quantitative traits with grain yield in rice (Oryza sativa L.)," J. of Bio-Science, 17(1): 77-82.

Pandey, V. R., P. K. Singh, O. P. Verma and P. Pandey. 2012. Inter-relationship and path coefficient estimation in rice under salt stress environment. Int. J. Agric. Res. 7: 16984. 
Singh, P. K., B. K. Dhakad, H. B. Singh and A. K. Singh. 2012. Genetic variability and association analysis in treated rice (Oryza sativa L.) with Trichoderma harzianum. Crop Res. 44: 141-45.

Singh, R., V. Yadav, D. N. Mishra and A. Yadav. 2018. Correlation and Path Analysis Studies in Rice (Oryza sativa L.). Journal of Pharmacognosy and Phytochemistry. SP1: 2084-2090.

Virmani, S. S., P.J. Jachuck, S.D. Chatterjee and M. I. Ahmad. 1998. Opportunities and challenges of developing hybrid rice technology for rainfed lowland and Boro ecosystem. In: Rainfed Rice for Sustainable Food Security (S.K. Mohanty, ed.). Cuttack, India. 53-62 pp.

Yuan, L. P. 1998. Hybrid rice breeding in China. In: Advances in Hybrid Rice Technology (Virmani SS, Siddiq EA, Muralidharan K, editors). Proc. $3^{\text {rd }}$ Intl. Symp. on Hybrid Rice. held on 14-16 November 1996, Hyderabad, India. 27-33 pp. 
